\title{
Malaysian clinical practice guidelines for management of diabetic foot: A synopsis for the primary care physician
}

\author{
Tharumaraja Thiruselvam, Aminudin Che-Ahmad, Ping Foo Wong, Afiza Hanun Ahmad@ \\ Hamid, Mohd Idham Hasan, Mohd Yazid Bajuri, Gurmeet Singh Sewa Singh, Vijiya Mala \\ Valayatham, Siti Norzalilah Abdul Majid, Hafizan Mohd Taji, Masfiza Abdul Hamid, \\ Ainol Haniza Kherul Anuwar, Mohd Aminuddin Mohd Yusof \\ Tharumaraja T, Che-Ahmad A, Wong PF, et al. Malaysian clinical practice guidelines for management of diabetic foot: A synopsis for the primary care \\ physician. Malays Fam Physician. 2021;16(1);103-113. https://doi.org/10.51866/cpg0001
}

\section{Keywords:}

diabetic foot, diabetic foot ulcer, diabetic neuropathy, screening, risk stratification

\section{Authors:}

Tharumaraja Thiruselvam (Corresponding author) MBBS(DU), MMed (Ortho) (USM) Department of Orthopaedics Hospital Kulim, Kedah Email: tharu64maraja@yahoo.com.au

Aminudin Che Ahmad MD (USM), MS Ortho (UKM) Department of Orthopaedics Traumatology \& Rehabilitation Pusat Perubatan Universiti Islam Antarabangsa Malaysia, Pahang Malaysia

Wong Ping Foo

MBBS (IMU), Dr Fam Med (UKM)

Klinik Kesihatan Cheras Baru

Kuala Lumpur, Malaysia

Afiza Hanun Ahmad@Hamid MD (UKM) M. Med Family Medicine (USM)

Klinik Kesihatan Hutan Melintang Perak, Malaysia

\section{Abstract}

Diabetic foot requires careful attention and coordinated management by a dedicated team. Screening, prevention, adequate assessment, and appropriate referral are crucial to prevent complications. Multimodal treatment and rehabilitation are recommended to ensure a better quality of life and reduction of amputation rate in people with diabetic foot.

\section{Introduction}

Diabetic foot is defined as infection, ulceration, or destruction of tissues of the foot associated with neuropathy and/or peripheral arterial disease (PAD) of people with diabetes mellitus (DM). ${ }^{1}$

According to the Malaysian National Health and Morbidity Surveys, the prevalence of diabetes has been increasing from $11.6 \%$ in 2006 to $15.2 \%$ in 2011 and further to $17.5 \%$ in 2015. The prevalence increased across age groups from 5.5\% among those 18 to 19 years of age to a peak of $39.1 \%$ among those 70 to 74 years of age. ${ }^{2}$ Overall, the cost of management of type 2 DM (T2DM) in 2011 was RM1.40 billion, which corresponded to $9.21 \%$ of the entire Ministry of Health $(\mathrm{MoH})$ budget. $^{3}$

The high prevalence of diabetes in adults increases the risk of foot problems, mainly due to neuropathy and/or PAD. ${ }^{4} \mathrm{Up}$ to $50 \%$ of people with DM are asymptomatic of diabetic peripheral neuropathy (DPN) 5 and about one million amputations are performed on people with diabetes each year worldwide. ${ }^{1}$ Diabetic foot requires careful attention and coordinated management, preferably by a multidisciplinary foot care team.

\section{Methods of Clinical Practice Guidelines Development}

The evidence-based Clinical Practice Guidelines (CPG) on Management of Diabetic Foot (Second Edition) were developed by a multidisciplinary Development Group from the $\mathrm{MoH}$ and Ministry of Education, guided by a multidisciplinary Review Committee. A systematic review method was used, starting with a protocol including objectives and clinical questions. Then a systematic literature search was carried out primarily using the Medline and Cochrane Systemic Review databases. The reference lists of all retrieved literature and guidelines were also searched to identify relevant studies. Experts in the field were also contacted for further relevant studies. References were also made to other existing CPGs on diabetic foot.

All literature retrieved were appraised using Critical Appraisal Skill Programme checklist, presented in evidence tables, and further discussed in each Development Group meeting. All statements and recommendations formulated were agreed upon by both the Development Group and Review Committee. Where evidence was insufficient, the recommendations were made using the expert opinion of the teams. The CPG was largely based on the findings of systematic reviews or meta-analyses and clinical trials, with local practices taken into consideration. 


\author{
Mohd Idham Hasan \\ MBBS (UQ), MS Ortho (UKM) \\ Foot Ankle (KKM) \\ Department of Orthopaedics \\ Hospital Putrajaya, Putrajaya \\ Malaysia
}

\section{Mohd Yazid Bajuri}

MD (UKM), MS Ortho (UKM)

Department of Orthopaedics \&

Traumatology, Pusat Perubatan

Universiti Kebangsaan Malaysia

Kuala Lumpur, Malaysia

Gurmeet Singh s/o Sewa Singh

MBBS (DU), MS Ortho (UKM)

Department of Orthopaedics

Hospital Pulau Pinang, Pulau Pinang

Malaysia

Vijiya Mala Valayatham

MBBS (UM), MRCP(UK)

Department of Medicine, Hospital

Putrajaya, Putrajaya, Malaysia

\section{Siti Norzalilah Abdul Majid}

MBBS(UM), MRehabMed (UM)

Department of Rehabilitation

Medicine, Hospital Rehabilitasi

Cheras, Kuala Lumpur, Malaysia

\section{Hafizan Mohd Tajri}

MBBCh (Ireland), MSurg (UKM)

Department of General Surgery

Hospital Kuala Lumpur, Kuala Lumpur

Malaysia

\section{Masfiza Abdul Hamid}

BPharm (USM)

Department of Pharmacy

Hospital Sultanah Bahiyah

Kedah, Malaysia

\section{Ainol Haniza Kherul Anuwar}

DDS (UGM), MCOH (UM)

Faculty of Dentistry, Universiti Malaya

Kuala Lumpur, Malaysia
The level of evidence was based on the US/ Canadian Preventive Services Task Force Level of Evidence, while the grading of recommendation used the principles of Grading Recommendations, Assessment, Development, and Evaluation (GRADE). The writing of the CPG followed strictly the requirement of Appraisal of Guidelines for Research and Evaluation (AGREE) II.

On completion, the draft of the CPG was reviewed by external reviewers and posted on the $\mathrm{MoH}$ Malaysia official website for any interested parties to give feedback. The draft was finally presented to the Technical Advisory Committee for CPG, and the Health Technology Assessment and CPG Council $\mathrm{MoH}$ Malaysia for final review and approval. The manuscript was then written based on the approved CPG as mentioned in Supporting Information section.

\section{Diagnosis and Assessment}

All people with diabetes should be assessed for diabetic foot at risk. They should be screened, diagnosed, investigated, classified, and stratified to ensure optimal management. Assessment of DPN should be performed at diagnosis and repeated annually. ${ }^{6}$ Early detection of diabetic foot at risk and appropriate interventions will minimize complications and healthcare costs. ${ }^{7}$

\section{History Taking}

Proper management of diabetic foot is initiated by good history taking, which includes general (risk factors for diabetic foot), medical (underlying concurrent medical condition), and individual diabetic foot history (vascular or neuropathic symptoms). Predictors for increased risk of foot ulceration in diabetes include a previous history of ulceration or lower extremity amputations and a longer duration of diabetes. ${ }^{8}$ Refer to the Diabetic Foot Assessment Form for full history taking on diabetic foot.

\section{Physical Examination}

Physical assessment is an important step in the screening and diagnosing of diabetic foot problems, including complications. This includes proper inspection and palpation of the foot.

\section{- Skin}

Skin changes due to vascular insufficiency may be present, for example, skin atrophy, nail atrophy, diminished pedal hair, prolonged capillary refill time ( $>2$ seconds), and reduced skin temperature.

\section{- Neurological}

A monofilament test and vibration perception are used to assess DPN, which is a major independent risk factor for diabetic foot ulceration. It may involve large fiber nerves (for touch, vibration, position perception, and muscle control), small fiber nerves (for thermal perception, pain, and autonomic function), or both. The commonly used screening tools are:

\section{Semmes-Weinstein Monofilament Examination}

A Semmes-Weinstein monofilament examination (SWME) is easy to perform and widely available locally. The examination uses a 5.07/10-g monofilament which exerts a buckling force when it bends. Inability to sense touch or pressure (>3 out of 10 sites) indicates loss of protective sensation. SWME should be combined with another modality in the screening of peripheral neuropathy. Refer to Figure 1.

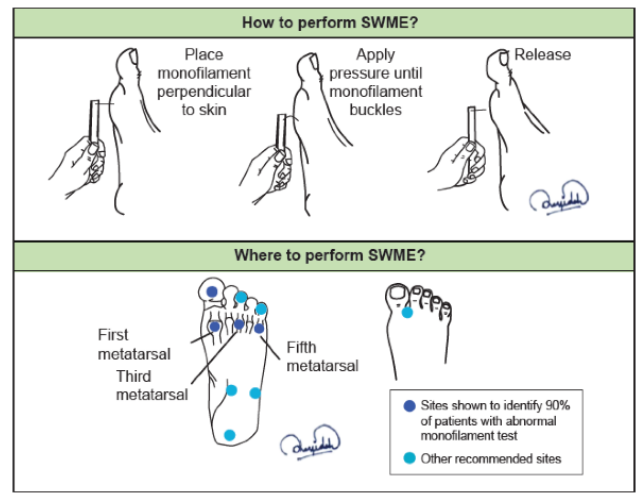

Figure 1. Semmes-Weinstein monofilament examination (SWME)

\section{Tuning Fork Test}

A tuning fork is used to detect the loss of vibration sense. The most commonly used tuning fork is $128 \mathrm{~Hz}$. Refer to Figure 2.

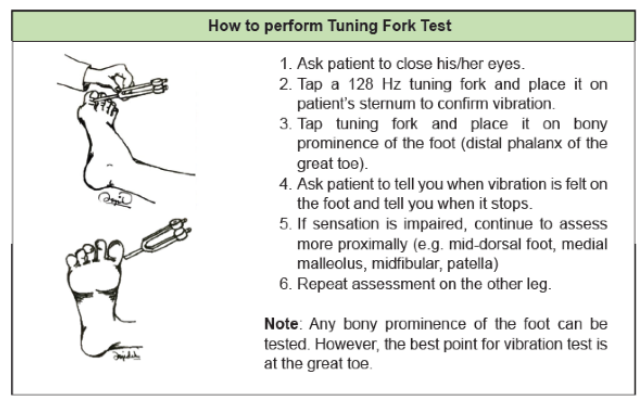

Figure 2. Tuning fork examination 
Mohd Aminuddin Mohd Yusof MD (UKM) MPH (Epid) (UM) Malaysia Health Technology Assessment Section (MaHTAS) Medical Development Division Ministry of Health Malaysia Purrajaya, Malaysia
Neuropathy should be assessed with 10-g monofilament and one other modality (e.g. pin prick, vibration sense with $128 \mathrm{~Hz}$ tuning fork, etc.). These increase the sensitivity of detecting peripheral neuropathy by $87 \% .^{6}$

\section{- Vascular}

Vascular assessment includes mandatory palpation of the femoral, popliteal, posterior tibial, and dorsalis pedis artery pulses. Critical limb ischemia is defined as rest pain with ulcers or tissue loss attributed to arterial occlusive disease. It is associated with substantial loss of limb and life. ${ }^{9}$

Palpation of foot pulses should be the initial screening method for PAD. Among the tests that can be used to exclude PAD are ${ }^{1}$ :

- Ankle-brachial index (normal value 0.9-1.3)

- Toe-brachial index (normal value $\geq 0.75$ )

- Continuous wave Doppler (presence of triphasic waveforms)
Thus, screening for DPN and PAD should be performed on all patients with diabetes at diagnosis and repeated at least annually. Those with DPN and PAD should be referred appropriately. Refer to Algorithm A.

\section{- Musculoskeletal}

Musculoskeletal complications in diabetic foot include ulcers, infections, and deformities (e.g. Charcot neuroarthropathy).

Conventional radiography may be helpful in diabetic foot for initial imaging to detect osteolysis, arterial calcification, gas shadow, malalignment, and peri-articular fragmentation.

Refer to the Diabetic Foot Assessment Form for the full physical examination of diabetic foot.

\section{Diabetic Foot Assessment Form ${ }^{10}$}

\begin{tabular}{|c|c|c|}
\hline \multicolumn{3}{|c|}{$\begin{array}{l}\text { DATE: } \\
\text { PERSONAL DATA }\end{array}$} \\
\hline \multirow{2}{*}{\multicolumn{3}{|c|}{$\begin{array}{l}\text { NAME: } \\
\text { IDENTIFICATION CARD NUMBER:- }\end{array}$}} \\
\hline & & \\
\hline $\begin{array}{l}\square \quad \text { Newly diagnosed (on admission) } \\
\square \text { High blood sugar: } \\
\square \text { Symptomatic: } \\
\square \text { Others: } \\
\square \text { Known case of Diabetes Mellitus } \\
\text { (DM) } \\
\text { Duration: } \\
\text { Date of diagnosis: __ years } \\
\text { Type of DM: } \\
\square \text { Type } 1 \\
\square \text { Type } 2 \\
\square \text { Others: }\end{array}$ & $\begin{array}{l}\text { Treatment: } \\
\square \quad \text { Never sought medical treatment } \\
\square \text { Self-treated } \\
\square \text { Traditional/alternative treatment } \\
\text { Current medical treatment: } \\
\square \quad \text { Nil } \\
\square \quad \text { Diet alone } \\
\square \text { Medication: } \\
\square \text { Oral Anti-Diabetic Agents: } \\
\quad \square \text { Insulin: } \\
\square \text { Combined: }\end{array}$ & $\begin{array}{l}\text { Other medical condition: } \\
\square \text { Ischemic Heart Disease } \\
\square \text { Stroke } \\
\square \text { Hypertension } \\
\square \text { Hyperlipidemia } \\
\square \text { Others: } \\
\text { Complications: } \\
\square \text { Peripheral Arterial Disease } \\
\square \text { Neuropathy } \\
\square \text { Nephropathy } \\
\square \text { Others: }\end{array}$ \\
\hline
\end{tabular}

\begin{tabular}{|l|c|c|c|c|c|}
\hline \multirow{2}{*}{} & \multicolumn{2}{|c|}{ Right } & \multicolumn{2}{c|}{ Left } & \multirow{2}{*}{ Description } \\
\cline { 2 - 6 } & Yes & No & Yes & No & \\
\hline Paresthesia (Pins \& Needles) & & & & & \\
\hline Claudication/Rest pain & & & & & \\
\hline Foot ulcer & & & & & \\
\hline Amputation & & & & & \\
\hline Orthosis/Prosthesis & & & & & \\
\hline \multirow{2}{*}{ Footwear } & Indoor & \multicolumn{2}{|c|}{ Outdoor } & \\
\hline & \multicolumn{2}{|c|}{} & & \\
\hline
\end{tabular}


(Kindly $\checkmark$ the appropriate box)

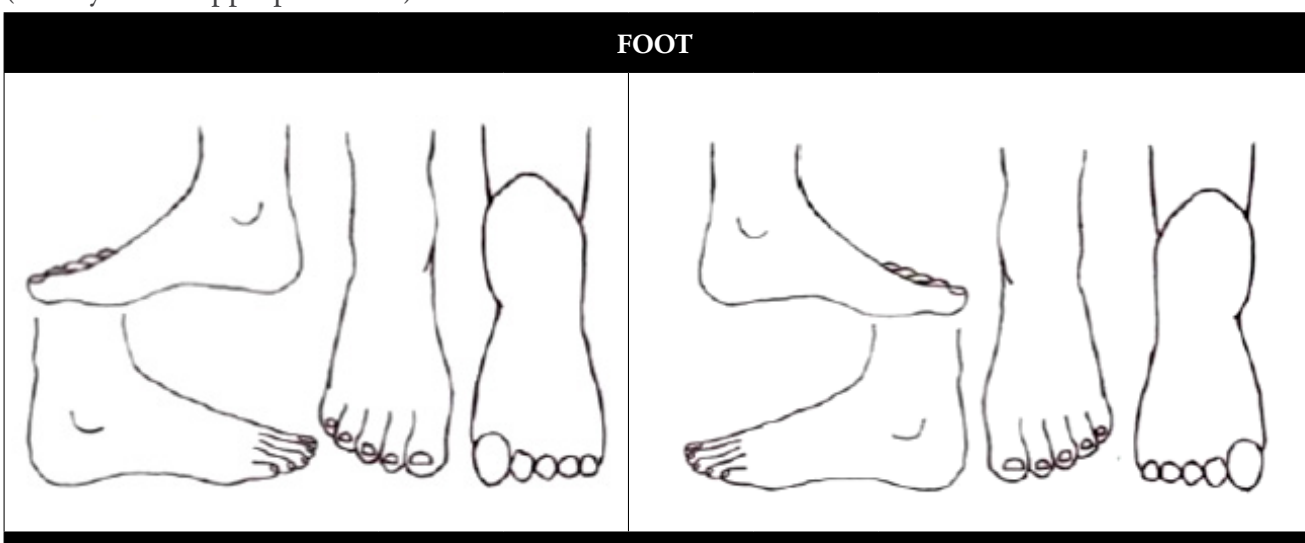

\begin{tabular}{|c|c|c|c|c|c|}
\hline \multicolumn{6}{|c|}{ GENERAL EXAMINATION } \\
\hline & \multicolumn{2}{|c|}{ Right } & \multicolumn{2}{|c|}{ Left } & \multirow{2}{*}{ Description } \\
\hline & Yes & No & Yes & No & \\
\hline \multicolumn{6}{|l|}{ Skin condition } \\
\hline \multicolumn{6}{|l|}{ Corn/callosity } \\
\hline \multicolumn{6}{|l|}{ Ulcer } \\
\hline \multicolumn{6}{|l|}{ Bunions } \\
\hline Lesser toe deformities & & & & & \\
\hline Charcot joints & & & & & \\
\hline
\end{tabular}

\begin{tabular}{|l|c|c|c|c|c|}
\hline \multirow{2}{*}{} & \multicolumn{2}{|c|}{ Right } & \multicolumn{2}{c|}{ Left } & \multirow{2}{*}{ Description } \\
\cline { 2 - 6 } & Yes & No & Yes & No & \\
\hline Muscle wasting & & & & & \\
\hline Presence of proprioception & & & & & \\
\hline $\begin{array}{l}\text { Abnormal monofilament test } \\
\text { (>3/10 ) }\end{array}$ & & & & & \\
\hline Presence of vibration perception & & & & & \\
\hline
\end{tabular}

\begin{tabular}{|l|c|c|c|c|c|}
\hline \multirow{2}{*}{} & \multicolumn{2}{|c|}{ Right } & \multicolumn{2}{c|}{ Left } & \multirow{2}{*}{ Description } \\
\cline { 2 - 6 } & Yes & No & Yes & No & \multirow{2}{*}{ D } \\
\hline Atrophic skin changes & & & & & \\
\hline Dystrophic nail & & & & & \\
\hline Absence of hair & & & & & \\
\hline Abnormal temperature gradient & & & & & \\
\hline Capillary refill $>3$ seconds & & & & & \\
\hline
\end{tabular}

\begin{tabular}{|l|c|c|c|c|c|c|c|}
\hline \multicolumn{7}{|c|}{ PALPABLE PULSE } \\
\hline $\begin{array}{l}\text { ++ (Normal) } \\
+\begin{array}{l}\text { (Weak) } \\
-(\text { Absent) }\end{array}\end{array}$ & \multicolumn{3}{|c|}{ Right } & \multicolumn{3}{c|}{ Left } & \multirow{2}{*}{ Description } \\
\cline { 2 - 7 } & ++ & + & - & ++ & + & - & \\
\hline Dorsalis pedis artery (DPA) & & & & & & & \\
\hline Posterior tibial artery (PTA) & & & & & & & \\
\hline Popliteal artery (PA) & & & & & & & \\
\hline Femoral artery (FA) & & & & & & & \\
\hline
\end{tabular}


(Kindly $\checkmark$ the appropriate box)

\begin{tabular}{|c|c|c|c|}
\hline & Right & Left & \multirow[t]{2}{*}{ Description } \\
\hline Brachial (mmHg) & & & \\
\hline Dorsalis pedis $(\mathrm{mmH}$ & & & \\
\hline Posterior tibial (mmF & & & \\
\hline $\mathrm{ABI}$ & & & $\begin{array}{l}\text { Use either DPA or PTA, whichever is } \\
\text { higher }\end{array}$ \\
\hline \multicolumn{4}{|c|}{ RISK STRATIFICATION } \\
\hline Low risk & \multicolumn{2}{|c|}{ Moderate risk } & High risk \\
\hline \multicolumn{4}{|c|}{ MANAGEMENT PLAN } \\
\hline $\begin{array}{l}\text { Referral: } \\
\square \text { Orthopedic } \\
\square \text { Vascular } \\
\square \text { Endocrine } \\
\square \text { Primary Care } \\
\square \text { Others: }\end{array}$ & $\begin{array}{l}\text { Follow-up: } \\
\square \text { 3-monthly } \\
\square \text { 6-monthly } \\
\square \text { Yearly } \\
\square \text { Others: }\end{array}$ & & $\begin{array}{l}\text { Foot care education checklist: } \\
\square \text { Foot hygiene } \\
\square \text { Nail care } \\
\square \text { Footwear advice } \\
\square \text { Routine foot check } \\
\square \text { Emollient use } \\
\square \text { Wound care } \\
\square \text { Recognizing active foot problems } \\
\text { (e.g. infection/erythema/ulcer) } \\
\square \text { Things to avoid (e.g. massage/ soak/ } \\
\text { reflexology/self-treatment) }\end{array}$ \\
\hline $\begin{array}{l}\text { Assessed by } \\
\text { Name: }\end{array}$ & Signature: & & Date: \\
\hline
\end{tabular}

\section{Risk Stratification}

A patient's current risk of developing a diabetic foot or requiring amputation is assessed using a practical risk stratification, as shown in Table $\mathbf{1}$.

Table 1. Diabetic foot risk stratification ${ }^{4}$

\begin{tabular}{|c|c|}
\hline Diabetic foot risk & Findings \\
\hline Normal & No abnormalities \\
\hline Low Risk & Callus alone \\
\hline Moderate Risk & $\begin{array}{l}\text { Any of the following: } \\
\text { - deformity } \\
\text { - neuropathy } \\
\text { - non-critical limb ischemia }\end{array}$ \\
\hline High Risk & $\begin{array}{l}\text { One of the following: } \\
\text { - previous ulceration } \\
\text { - previous amputation } \\
\text { - on renal replacement therapy } \\
\text { - neuropathy and non-critical limb ischemia } \\
\text { - neuropathy with callus and/or deformity } \\
\text { - non-critical limb ischemia with callus and/or deformity }\end{array}$ \\
\hline Active Diabetic Foot Problem & $\begin{array}{l}\text { Any of the following: } \\
\text { - ulceration } \\
\text { - infection } \\
\text { - critical limb ischemia } \\
\text { - gangrene } \\
\text { suspicion of an acute Charcot neuroarthropathy, or an } \\
\text { unexplained hot, red, swollen foot with or without pain }\end{array}$ \\
\hline
\end{tabular}




\section{Classification}

The University of Texas Classification ${ }^{11}$ is the preferred classification for diabetic foot and is useful to decide on the further management of the diabetic foot (refer Table 2). Refer to Algorithm B.

Table 2. University of Texas classification of diabetic foot ulcers

\begin{tabular}{|c|c|c|c|c|}
\hline STAGE & GRADE 0 & GRADE I & GRADE II & GRADE III \\
\hline STAGE A & $\begin{array}{c}\text { Pre- or post-ulcerative } \\
\text { lesion completely } \\
\text { epithelialized }\end{array}$ & $\begin{array}{c}\text { Superficial wound, } \\
\text { not involving tendon, } \\
\text { capsule, or bone }\end{array}$ & $\begin{array}{c}\text { Wound } \\
\text { penetrating to } \\
\text { tendon or capsule }\end{array}$ & $\begin{array}{c}\text { Wound } \\
\text { penetrating to } \\
\text { bone or joint }\end{array}$ \\
\hline STAGE B & With infection & With infection & With infection & With infection \\
\hline STAGE C & With ischemia & With ischemia & With ischemia & With ischemia \\
\hline STAGE D & $\begin{array}{c}\text { With infection } \\
\text { and ischemia }\end{array}$ & $\begin{array}{c}\text { With infection } \\
\text { and ischemia }\end{array}$ & $\begin{array}{c}\text { With infection } \\
\text { and ischemia }\end{array}$ & $\begin{array}{c}\text { With infection } \\
\text { and ischemia }\end{array}$ \\
\hline
\end{tabular}

\section{Prevention}

Patient education should be an integral part of the management of diabetic foot. It should be given at least annually and more frequently in higher-risk patients. Glycemic control (with minimization of hypoglycemia) should be individualized.

Patients should be advised on appropriate footwear according to the foot risk. Its importance increases with a higher risk of developing diabetic foot ulcer. Recommendations of footwear according to foot risk status are shown in Table 3. ${ }^{12}$

Table 3. Footwear advice ${ }^{12}$

\begin{tabular}{|l|l|}
\hline Risk status & \multicolumn{1}{c|}{ Actions } \\
\hline All foot at risk & $\begin{array}{l}\text { - Advise the use of footwear that fits, protects, and accommodates the shape of } \\
\text { the feet (with socks). }\end{array}$ \\
\hline Moderate or high risk & $\begin{array}{l}\text { - Prescribe footwear with: } \\
\text { custom-made in-shoe orthoses or insoles for people with a foot deformity } \\
\text { or pre-ulcerative lesions } \\
\text { - off-loading orthoses or insoles for people with healed plantar foot ulcer } \\
\text { Review prescribed footwear periodically to ensure it still fits, protects, and } \\
\text { supports the foot }\end{array}$ \\
\hline Foot ulceration & \begin{tabular}{l} 
Advise the wearing of footwear at all times, both indoors and outdoors \\
\hline
\end{tabular} \\
\hline
\end{tabular}

Patients with diabetic foot should be referred early for preventive surgery if all other modalities have failed. It should be performed by orthopedic surgeons trained in the procedures to prevent ulceration or re-ulceration in diabetic patients with foot deformity e.g. restricted ankle dorsiflexion, equinus contracture, claw toe, hammer toe, or mallet toe.

\section{Treatment}

\section{- Pharmacotherapy}

Appropriate analgesia should be considered in painful diabetic foot. In neuropathic pain, adjuvants are used at all steps of the analgesic ladder. ${ }^{13}$ Examples of adjuvants are antidepressants (e.g. amitriptyline or duloxetine) and anticonvulsants (e.g. gabapentin or pregabalin). ${ }^{14}$
Antibiotics should not be used unless there are local or systemic symptoms of infection. Local treatment including surgical debridement is important to be considered as part of the management. Antibiotic used for treatment should be based on the most recent culture and sensitivity report. ${ }^{15}$

In diabetic foot, antibiotics should be given according to the disease severity, care setting, patient's preference, clinical situation and medical history. If more than one regimen is appropriate, the regimen with lowest cost should be selected. For moderate and severe infections, broad spectrum antibiotics are used initially until culture and sensitivity results are available. Antibiotics should not be given for $^{4}$ :

- prevention of infections in diabetic foot

- >14 days for the treatment of mild soft tissue infection in diabetic foot 


\section{- Wound Management}

\section{Wound Dressings}

Advanced wound dressings may be offered in diabetic foot ulcer; refer to Table 4.

Table 4. Types of wound dressing in diabetic foot ${ }^{16}$

\begin{tabular}{|c|c|c|c|c|c|c|}
\hline No. & Types of dressing & Advantages & Disadvantages & Indications & Contraindications & $\begin{array}{l}\text { Review } \\
\text { intervals }\end{array}$ \\
\hline \multicolumn{7}{|c|}{ Basic wound contact dressings } \\
\hline 1. & $\begin{array}{l}\text { Gauze/basic absorbent } \\
\text { with paraffin or } \\
\text { similar (antiseptics or } \\
\text { antibiotics) }\end{array}$ & $\begin{array}{l}\text { - Reduces } \\
\text { adherence of } \\
\text { dressing to the } \\
\text { wound } \\
\text { - Widely available }\end{array}$ & $\begin{array}{l}\text { - Minimal exudate } \\
\text { absorption } \\
\text { - Requires } \\
\text { secondary } \\
\text { dressing }\end{array}$ & All wounds & Allergy & Daily \\
\hline \multicolumn{7}{|c|}{ Advanced wound dressings } \\
\hline 1. & Hydrogel & $\begin{array}{l}\text { - Provides moist } \\
\text { environment } \\
\text { - Acts as enzymatic } \\
\text { debridement } \\
\text { - Promotes } \\
\text { granulation }\end{array}$ & $\begin{array}{l}\text { Requires } \\
\text { secondary } \\
\text { dressing }\end{array}$ & $\begin{array}{l}\text { - Sloughy } \\
\text { wound } \\
\text { - Dry } \\
\text { wounds }\end{array}$ & $\begin{array}{l}\text { - Highly exudative } \\
\text { wounds } \\
\text { - Allergy }\end{array}$ & $1-2$ days \\
\hline 2. & Alginate & $\begin{array}{l}\text { - Forms gel } \\
\text { on wound } \\
\text { and maintain } \\
\text { moisture } \\
\text { - Acts as cavity } \\
\text { filler } \\
\text { - Absorbent in } \\
\text { exudative wounds } \\
\text { - Promotes } \\
\text { hemostasis } \\
\text { - Low allergenic }\end{array}$ & $\begin{array}{l}\text { Requires } \\
\text { secondary } \\
\text { dressing } \\
\text { Gel can be } \\
\text { confused with } \\
\text { slough or pus in } \\
\text { wound }\end{array}$ & 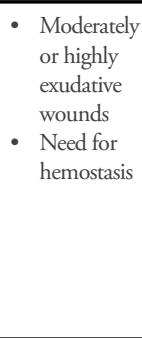 & $\begin{array}{l}\text { - Dry wounds } \\
\text { - Allergy }\end{array}$ & $2-3$ days \\
\hline 3. & Hydrofibre & $\begin{array}{l}\text { - } \text { Maintains } \\
\text { moisture } \\
\text { - Longer wear time } \\
\text { - Non-traumatic } \\
\text { upon removal } \\
\text { - Reduces risk of } \\
\text { maceration } \\
\text { - Can be used on } \\
\text { infected wounds }\end{array}$ & $\begin{array}{l}\text { - Not helpful for } \\
\text { dry wounds } \\
\text { - Requires } \\
\text { secondary } \\
\text { dressings }\end{array}$ & $\begin{array}{l}\text { Moderately } \\
\text { or highly } \\
\text { exudative } \\
\text { wounds }\end{array}$ & Allergy & $2-5$ days \\
\hline 4. & Foam & $\begin{array}{ll}\text { - } & \text { Maintains } \\
& \text { moisture } \\
\text { - Highly absorbent } \\
\text { - } \text { Cushioning } \\
\text { property }\end{array}$ & Limited size & $\begin{array}{l}\text { Moderately } \\
\text { or highly } \\
\text { exudative } \\
\text { wounds }\end{array}$ & $\begin{array}{l}\text { Dry wounds } \\
\text { - Wounds that } \\
\text { need frequent } \\
\text { review }\end{array}$ & $2-3$ days \\
\hline 5. & Hydrocolloid & $\begin{array}{l}\text { - Maintains } \\
\text { moisture } \\
\text { - Cleans and } \\
\text { debrides by } \\
\text { autolysis } \\
\text { - Easy to use } \\
\text { - Waterproof }\end{array}$ & $\begin{array}{l}\text { Induces peri-wound } \\
\text { maceration }\end{array}$ & $\begin{array}{l}\text { Mildly to } \\
\text { moderately } \\
\text { exudative } \\
\text { wounds }\end{array}$ & $\begin{array}{ll}\text { - Dry wounds } \\
\text { - Infection } \\
\text { - Highly exudative } \\
\text { wounds }\end{array}$ & $2-3$ days \\
\hline 6. & Silver & 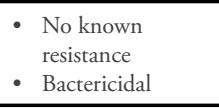 & $\begin{array}{l}\text { Some silver dressings } \\
\text { discolor the wound }\end{array}$ & $\begin{array}{l}\text { Infective } \\
\text { wounds }\end{array}$ & Allergy & $3-5$ days \\
\hline 7. & Others & $\begin{array}{l}\text { Not widely used - so } \\
\text { dressings (cultured ep }\end{array}$ & $\begin{array}{l}\text { e may be used in } s \\
\text { lermis, growth factor }\end{array}$ & $\begin{array}{l}\text { ialized centers } \\
\text { tem cells, etc.) }\end{array}$ & g. collagen, matrix, & regenerative \\
\hline
\end{tabular}

\section{Adjuvant Therapy}

Adjuvant therapy may be offered in delayed wound healing in diabetic foot with good vascularity.

- Negative pressure wound therapy is a procedure in which a vacuum dressing is used to promote wound healing. It is used for clean exudative wounds with poor granulation. ${ }^{17}$

- Maggot debridement therapy is used for the debridement of wounds with necrotic tissue. It shows better wound closure (>50\% of wound area) after 10 days compared with autolytic debridement with hydrogel in diabetic foot ulcer. ${ }^{18}$ 
- Hyperbaric oxygen therapy is used to increase oxygenation and antimicrobial effect that can improve the healing of chronic ulcers. ${ }^{19-21}$

\section{Revascularization}

Revascularization should be offered in diabetic patients with PAD. Surgical debridement by trained healthcare providers should be considered in diabetic foot ulcer that fails to respond to non-surgical debridement, or is deep and infected at presentation.

\section{Rehabilitation}

Off-loading should be offered to people with plantar diabetic foot ulcer. Those with diabetic foot who have had amputation should be referred for rehabilitation.

Algorithms A and B summarize the management of diabetic foot.

Algorithm A. Screening of diabetic foot

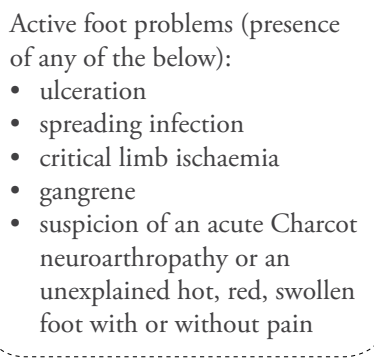

- spreading infection

- critical limb ischaemia

- gangrene

- suspicion of an acute Charcot neuroarthropathy or an unexplained hot, red, swollen foot with or without pain

r.

\section{All people with diabetes}

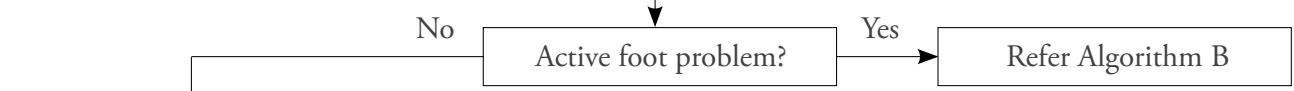

Previous history of ulceration, amputation, or on renal replacement therapy?

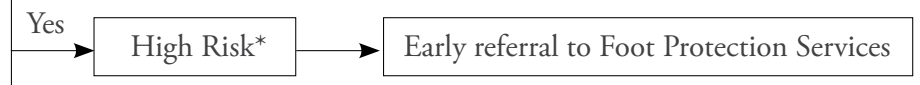

skin

- neurological

- vascular

- musculoskeletal
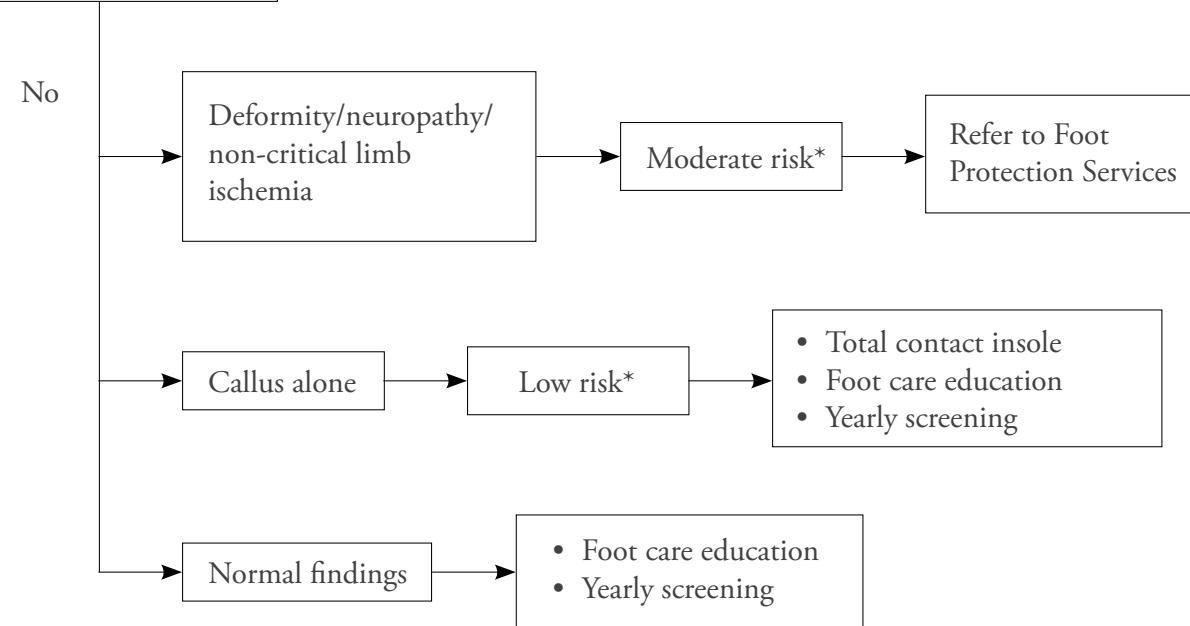

* Refer to Table 1 on diabetic foot risk stratification. 
Algorithm B. Active foot problems (with risk stratification)

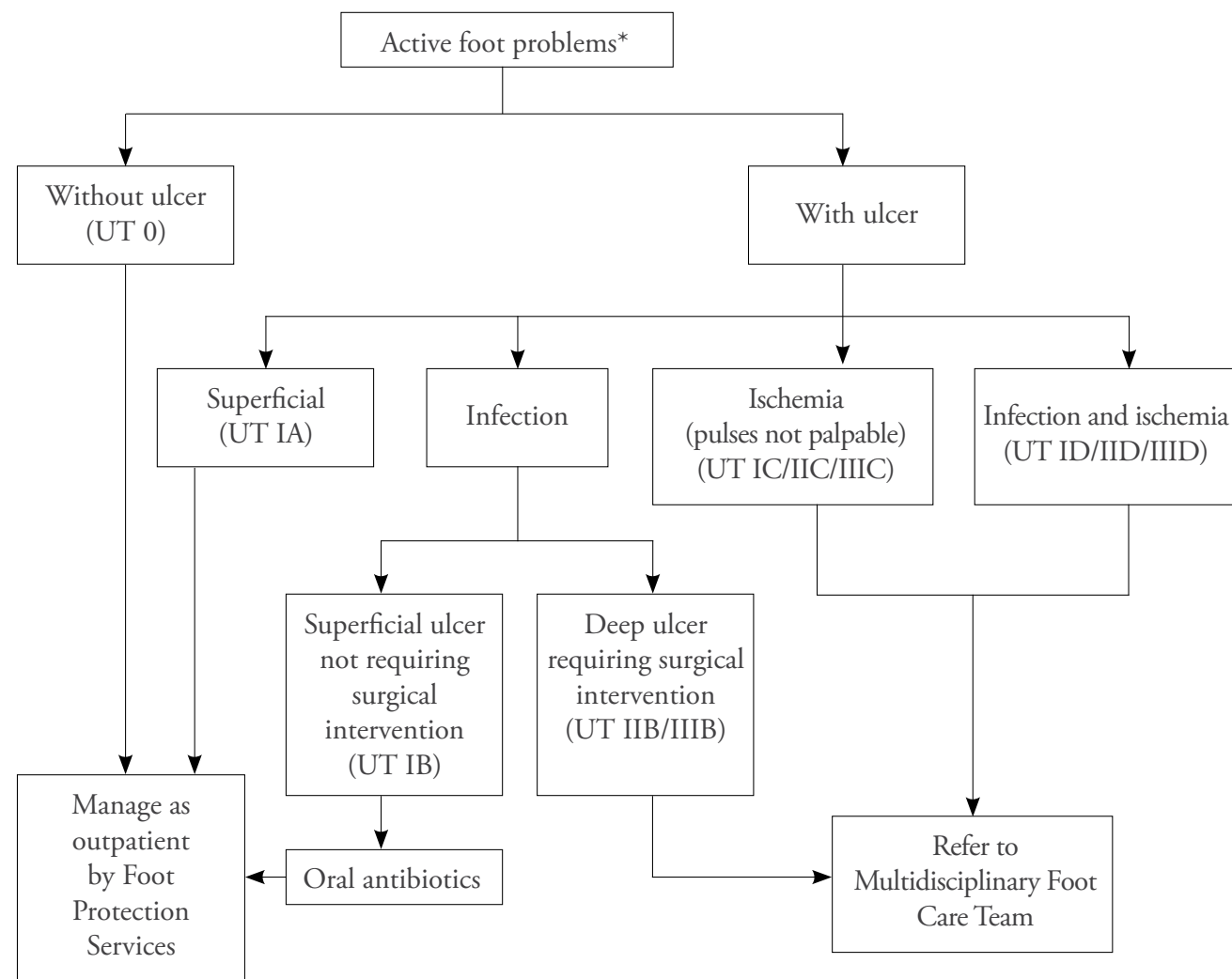

* Refer urgently for admission if patients present with general illness (e.g. sepsis or diabetic emergencies) irrespective of foot problems.

* UT $=$ University of Texas

\section{Referral}

People who are at moderate or high risk of developing a diabetic foot problem are referred to multidisciplinary professionals in the field of podiatry, diabetology, biomechanics and orthoses, and wound care. ${ }^{4}$ People with a limb-threatening or life-threatening diabetic foot problem should be referred urgently and managed under specialist care. Examples of such conditions include ulceration with fever or any signs of sepsis, critical limb ischemia, deep-seated soft tissue or bone infection, and gangrene.

The recommended referral schedule for diabetic foot is shown in Table $\mathbf{5}$.

Table 5. Recommended referral schedule

\begin{tabular}{|l|l|} 
Diabetic foot risk & \multicolumn{1}{c}{ Findings } \\
\hline Normal/Low risk & No referral needed-yearly review at primary care \\
\hline Moderate risk & Referral within 3 months to foot protection services \\
\hline High risk & Early referral within 2 weeks to foot protection services \\
\hline Active diabetic foot problem & Urgent referral within 24 hours to multidisciplinary foot care team \\
\hline
\end{tabular}


The referral should be addressed to:

1. The Foot Protection Service, which provides prevention and treatment of simple active diabetic foot problems in the community that do not require admission. The team should be led by a Family Medicine Specialist or physician with special training in diabetic foot problems and supported by podiatrist, diabetic team (including diabetic educator), wound care team, and rehabilitation services.
2. The multidisciplinary foot care service, which manages active or complicated diabetic foot problems in the hospital. The team is led by an orthopedic surgeon and/ or physician. Subsequent referral to other specialties is made according to the main problem presented by the patient.

\section{Monitoring and Follow-up}

Frequency of monitoring of patients with diabetic foot depends on risk stratification as shown in Table 6 below:

Table 6. Frequency of Monitoring for Diabetic Foot

\begin{tabular}{|c|c|c|c|c|}
\hline \multirow{2}{*}{ Risk } & \multirow{2}{*}{ Low risk } & \multirow{2}{*}{ Moderate risk } & \multicolumn{2}{|c|}{ High risk } \\
\cline { 4 - 5 } & & & No immediate concern & Immediate concern \\
\hline Frequency & Annually & $3-6$ months & $1-2$ months & $1-2$ weeks \\
\hline
\end{tabular}

\section{Supporting Information}

Details of the evidence supporting the above statements can be found in Clinical Practice Guidelines on the Management of Diabetic Foot (Second Edition) 2018, available on the following websites: http://www.moh.gov. my (Ministry of Health Malaysia) and http:// www.acadmed.org.my (Academy of Medicine). Corresponding organization: CPG Secretariat, Health Technology Assessment Section, Medical Development Division, Ministry of Health Malaysia; contactable at htamalaysia@ moh.gov.my.

\section{References}

1. Bakker K, Apelqvist J, Lipsky BA, et al.; International Working Group on the Diabetic Foot. The 2015 IWGDF guidance documents on prevention and management of foot problems in diabetes: development of an evidence-based global consensus. Diabetes Metab Res Rev. 2016;32 Suppl 1:2-6.

2. Tahir A, Muhammad FMY, Abdul AAG, et al (eds.). National Health and Morbidity Survey: Non-Communicable Diseases, Risk Factors and other health problems. Institute for Public Health. 2015.

3. Feisul IM, Azmi S, Mohd Rizal AM, et al. What are the direct medical costs of managing Type 2 Diabetes Mellitus in Malaysia? Med J Malaysia. 2017;72(5):271-277.

4. National Institute for Health and Care Excellence. Diabetic Foot Problems: Prevention and Management. London: NICE; 2015.

5. Pop-Busui R, Boulton AJ, Feldman EL, et al. Diabetic Neuropathy: A Position Statement by the American Diabetes Association. Diabetes Care. 2017;40(1):136-154.
6. Malaysian Endocrine \& Metabolic Society and Ministry of Health Malaysia. Management of Type 2 Diabetes Mellitus (5th Edition). Kuala Lumpur: MEMS \& MOH; 2015.

7. Ministry of Health Malaysia. Management of Diabetic Foot. Kuala Lumpur: MoH; 2004

8. Crawford F, Cezard G, Chappell FM, et al A systematic review and individual patient data meta-analysis of prognostic factors for foot ulceration in people with diabetes: the international research collaboration for the prediction of diabetic foot ulcerations (PODUS). Health Technol Assess.

2015;19(57):1-210

9. Slovut DP, Sullivan TM. Critical limb ischemia: medical and surgical management. Vasc Med. 2008;13(3):281-291.

10. A Che-Ahmad, NF Mustafa, N Alias, et al.Evaluation of foot at risk among diabetic patients using diabetic foot assessment protocol in Malaysia. IIUM \& MOH, 2012. (unpublished document)
11. Lavery LA, Armstrong DG, Harkless LB. Classification of diabetic foot wounds. J Foot Ankle Surg. 1996;35(6):528-531

12. vanNetten JJ, Lazzarini PA, Armstrong DG, et al. Diabetic Foot Australia guideline on footwear for people with diabetes. J Foot Ankle Res. 2018;11:2.

13. Ministry of Health Malaysia. Pain as the 5th Vital Sign Guidelines: 2nd Edition. Kuala Lumpur: MoH; 2013.

14. Ministry of Health Malaysia. Pain Management Handbook. Kuala Lumpur: MoH. 2013

15. Pharmaceutical Services Division, Ministry of Health Malaysia. National Antibiotic Guideline (Second Edition). Petaling Jaya: $\mathrm{MoH} ; 2014$

16. Ministry of Health. Wound Care Manual. Kuala Lumpur: MoH; 2014 
17. Dumville JC, Hinchliffe RJ, Cullum N, et al. Negative pressure wound therapy for treating foot wounds in people with diabetes mellitus. Cochrane Database Syst Rev. 2013;(10):CD010318

18. Ministry of Health Malaysia. Maggot debridement therapy. Kuala Lumpur: $\mathrm{MOH}$; 2008.
19. Kranke P, Bennett MH, Martyn-St James $M$, et al. Hyperbaric oxygen therapy for chronic wounds. Cochrane Database Syst Rev. 2015;(6):CD004123.

20. MohdYazid B, Ayesyah A, Nurhanani AB, et al. The Physiological, Biochemical and Quality of Life Changes in Chronic Diabetic Foot Ulcer after Hyperbaric Oxygen Therapy. Med \& Health. 2017;12(2): 210-219.
21. Nik Hisamuddin NAR, Wan Mohd Zahiruddin WN , Mohd Yazid B , Rahmah S Use of hyperbaric oxygen therapy (HBOT) in chronic diabetic wound - A randomised trial. Med. J. Malaysia, 2019 Oct;74(5):418-424. 